\title{
Jurnal Manajemen
}

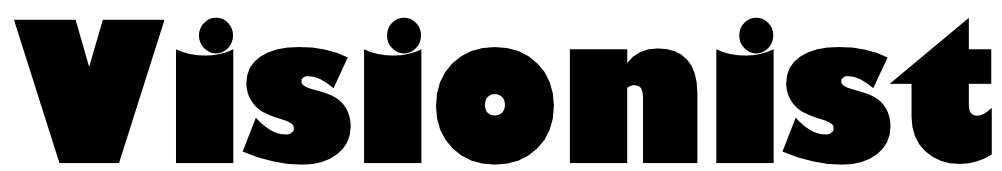

Vol. 9, Nomor 2-September 2020

ANALISIS HASIL PEMERIKSAAN PAJAK UNTUK MEMETAKAN (MAPPING) KLASIFIKASI LAPANGAN USAHA (KLU) WAJIB PAJAK BADAN YANG POTENSIAL DI KANTOR WILAYAH DJP BENGKULU DAN LAMPUNG PERIODE TAHUN 2016-2019 Agah Rahadian, Tina Miniawati Barusman dan Haninun

ANALISIS PERENCANAAN SEKTOR PERTANIAN BERBASIS KORPORASI

..Indriati Agustina Gultom, Ayu Kartika Puspa, Yanuarius Yanu

Dharmawan, Achmad Subing

PENGARUH KEPEMIMPINAN, MOTIVASI KERJA DAN BUDAYA KERJA TERHADAP KINERJA KARYAWAN DI PT. AGRO MULTIGUNA SEJATI

Iskandar Muda Pohan, Andala Rama Putra Barusman dan M Oktaviannur

PENGARUH KUALITAS LAYANAN DAN CITRA MEREK TERHADAP LOYALITAS NASABAH TABUNGAN BRITAMA BRI CABANG TELUK BETUNG MELALUI KEPUASAN NASABAH

Travel Valeri Mercuri, Andala Rama Putra Barusman dan M Oktaviannur 26-32

PENGARUH JOB ROTATION (ROTASI PEKERJAAN), JOB ASSIGNMENT (PENUGASAN PEKERJAAN) DAN MENTORING TERHADAP PROGRAM PENGEMBANGAN TALENTA KARYAWAN PADA PT PERUSAHAAN GAS NEGARA TBK

Wendi Purwanto, Tina Miniawati Barusman dan Habiburrahman

PENGARUH MOTIVASI DAN PENGEMBANGAN KARIER TERHADAP KINERJA PEGAWAI DI DINAS PENDIDIKAN KABUPATEN TULANG BAWANG

Wiwi Nurhayati, Iskandar Ali Alam dan M Oktaviannur

PENGARUH KOMPETENSI SUMBER DAYA MANUSIA, PENERAPAN SISTEM PENGENDALIAN INTERN PEMERINTAH, PENERAPAN STANDAR AKUNTANSI PEMERINTAHAN DAN PEMANFAATAN TEKNOLOGI INFORMASI TERHADAP KUALITAS LAPORAN KEUANGAN PADA INSTANSI PEMERINTAH YANG BERSTATUS BADAN LAYANAN UMUM DI PROVINSI LAMPUNG Yana Marisa, Defrizal dan Hendri Dunan 46-51

ANALISIS DAMPAK INDUSTRI STOCKPILE BATU BARA TERHADAP LINGKUNGAN DAN TINGKAT KESEHATAN MASYARAKAT

\begin{tabular}{|c|c|c|c|c|c|}
\hline $\begin{array}{c}\text { Jurnal Manajemen } \\
\text { Visionist }\end{array}$ & Volume 9 & Nomor 2 & $\begin{array}{c}\text { Halaman } \\
1-59\end{array}$ & $\begin{array}{c}\text { Bandar Lampung } \\
\text { Sept 2020 }\end{array}$ & $\begin{array}{c}\text { ISSN } \\
1411-4186\end{array}$ \\
\hline
\end{tabular}




\section{Jurnal Manajemen

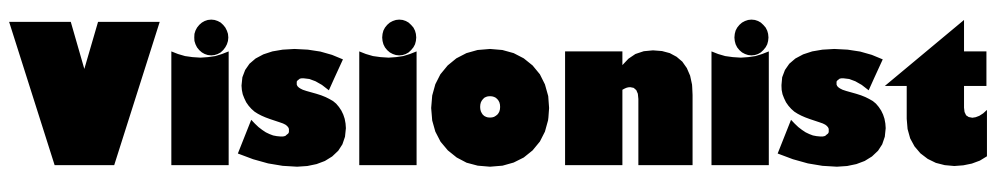 \\ Volume 9, Nomor 2 - September 2020}

\section{DEWAN PENYUNTING}

Penyunting Ahli Sudarsono (Ketua)

Sri Utami Kuntjoro

Sinung Hendratno

Agus Wahyudi

Abdul Basit

\section{Penyunting Pelaksana \\ Budhi Waskito \\ Ardansyah \\ Eka Kusmayadi \\ Zainal Abidin}

Alamat:

Jl. Z.A. Pagar Alam No. 89, Bandar Lampung Tel. 0721- 789825; Fax. 0721 - 770261

Email: visionist@ubl.ac.id

Diterbitkan oleh:

Program Studi Manajemen (S2) Program Pascasarjana Universitas Bandar Lampung 


\title{
Analisis Hasil Pemeriksaan Pajak untuk Memetakan (Mapping) Klasifikasi Lapangan Usaha (KLU) Wajib Pajak Badan yang Potensial di Kantor Wilayah Djp Bengkulu dan Lampung Periode Tahun 2016-2019
}

\author{
Agah Rahadiawan', Tina Miniawati Barusman', Haninun ${ }^{3}$ \\ Program Studi Magister Manajemen Universitas Bandar Lampung
}

\begin{tabular}{|c|}
\hline Abstrak \\
\hline $\begin{array}{l}\text { Kantor Wilayah DJP Bengkulu dan Lampung periode tahun 2016-2019. Penelitian ini menggunakan metode } \\
\text { deskriptif kualitatif dengan proses pengolahan data menggunakan statistika deskriptif, dimana terhadap data- } \\
\text { data yang diperoleh kemudian diolah dan disajikan dalam tabel dan grafik. Dari hasil penelitian ini dapat } \\
\text { diketahui bahwa Wajib Pajak Badan yang potensial hasil pemeriksaan pajak dapat dipetakan mengikuti pola } \\
\text { Wajib Pajak Badan berdasarkan penerimaan pajak per-sektor usaha atau Klasifikasi Lapangan Usaha (KLU). } \\
\text { Sektor usaha yang potensial tersebut adalah Idustri Pengolahan (kode KLU : 10 s.d. 33) dan Pertambangan Dan } \\
\text { Penggalian (kode KLU : 05 s.d. O9). Selain itu guna mengoptimalkan penerimaan dari pemeriksaan pajak } \\
\text { sebaiknya lebih mengedepankan penerapan kebijakan Pemeriksaan Khusus bagi Wajib Pajak Badan karena } \\
\text { cenderung menghasilkan penerimaan pajak cukup besar. } \\
\text { Penelitian ini bertujuan untuk menganalisis hasil pemeriksaan pajak untuk memetakan (mapping) Klasifikasi } \\
\text { Lapangan Usaha (KLU) Wajib Pajak Badan yang potensial di pajak. }\end{array}$ \\
\hline $\begin{array}{c}\text { Kata Kunci: Wajib Pajak, Pemeriksaan Pajak, Pemeriksan Pajak, Klasifikasi Lapangan Usaha (KLU), } \\
\text { Sektor Usaha, Penerimaan Pajak }\end{array}$ \\
\hline
\end{tabular}

\section{Pendahuluan}

Dalam rangka meningkatkan pembangunan nasional agar dapat terus berkembang maka dibutuhkan adanya penerimaan negara. Penerimaan dari sektor pajak merupakan salah satu sumber utama penerimaan pemerintah Indonesia dalam pembiayaan pembangunan selain penerimaan dari sumber daya alam berupa minyak dan gas bumi. Pada tahun 1983 Indonesia mengalami perubahan sistem perpajakan dari official assessment menjadi self assessment. Self Assessment System merupakan sistem pemungutan pajak yang memberi wewenang, kepercayaan, dan tanggung jawab kepada wajib pajak untuk menghitung, memperhitungkan, membayar, dan melaporkan sendiri besarnya pajak yang harus dibayar (Waluyo 2011). Namun Self assessment system dalam praktiknya menimbulkan konsekuensi kepada Wajib Pajak untuk siap menghadapi pengawasan oleh Direktorat Jenderal Pajak. Diharapkan dengan adanya kegiatan pengawasan maka kecurangan Wajib Pajak dapat berkurang dan kepatuhan Wajib Pajak dapat meningkat seperti menyampaikan surat pemberitahuan, pembukuan dan informasi lain yang relevan serta membayar pajak dengan tepat waktu sesuai dengan yang telah ditentukan oleh peraturan perpajakan. Kegiatan pengawasan ini dilaksanakan melalui pengawasan administratif, penerapan sanksi, penangihan dan penyidikan pajak. Bentuk pengawasan yang dilakukan Direktorat Jenderal Pajak ini didasarkan pada Pasal 29 Undang-Undang No.28 Tahun 2007 tentang Perubahan Ketiga Undang-Undang No.6 Tahun 1983 Tentang Ketentuan Umun dan Tata Cara Perpajakan (Undang-undang KUP) yang menyatakan Direktorat Jenderal Pajak dalam rangka pengawasan berwenang melakukan pemeriksaan untuk menguji kepatuhan pemenuhan kewajiban perpajakan dan tujuan lain untuk melaksanakan ketentuan peraturan perundang-undangan yang berlaku.

Berdasarkan pasal 4 huruf a Peraturan Direktur Jenderal Pajak Nomor : PER-23/PJ/2013 tentang Standar Pemeriksaan, dijelaskan bahwa "Pelaksanaan pemeriksaan harus didahului dengan persiapan pemeriksaan yang baik sesuai dengan tujuan pemeriksaan, yang paling sedikit meliputi kegiatan mengumpulkan dan mempelajari data Wajib Pajak, menyusun Rencana Pemeriksaan (audit plan), dan menyusun Program Pemeriksaan (audit program), serta mendapatkan pengawasan yang seksama." Kemudian dijelaskan kembali pada pasal 4 huruf a angka 1, bahwa kegiatan mengumpulkan dan mempelajari data Wajib Pajak, meliputi antara lain mempelajari 
profil Wajib Pajak. Cakupan profil Wajib Pajak itu sendiri antara lain adalah jenis usaha dan Klasifikasi Lapangan Usaha (KLU).

Sesuai Surat Edaran Direktur Jenderal Pajak Nomor : SE-03/PJ/2013 tentang Klasifikasi Lapangan Usaha Wajib Pajak, dijelaskan bahwa KLU digunakan untuk :

a. Tata Usaha Wajib Pajak, seperti data Kelompok Kegiatan Ekonomi Wajib Pajak dalam Master File Wajib Pajak, Kelompok Kegiatan Ekonomi pada Surat Pemberitahuan;

b. Dasar penyusunan Norma Penghitungan Penghasilan Neto;

c. Keperluan lainnya, seperti evaluasi penerimaan pajak sektoral, mapping potensi pajak sektoral, penentuan Wajib Pajak berisiko berbasis Benchmark Behavioral Model.

Berdasarkan kegunaan KLU tersebut, maka perlu diperhatikan mengenai karakteristik dari Wajib Pajak yang dilakukan pemeriksaan pajak dan jenis pemeriksaan pajaknya. Selain itu pemetaan potensi pajak sesuai geografi yang kuat di beberapa sektor usaha di masing-masing daerah diharapkan dapat menjadikan program pemeriksaan pajak pada tingkat kantor wilayah dapat berjalan lebih efektif dan pada akhirnya dapat meningkatkan penerimaan pajak secara nasional.

Berdasarkan latar belakang di atas maka rumusan masalah penelitian ini bertujuan untuk mengetahui bagaimana pemetaan (mapping) Klasifikasi Lapangan Usaha (KLU) Wajib Pajak Badan yang potensial di Kantor Wilayah DJP Bengkulu dan Lampung dengan menggunakan data hasil pemeriksaan pajak dan apa saja sektor usaha atau Klasifikasi Lapangan Usaha (KLU) Wajib Pajak Badan yang potensial yang kemungkinan menghasilkan penerimaan pajak yang besar bagi Kantor Wilayah DJP Bengkulu dan Lampung berdasarkan pemetaan (mapping) tersebut.

\section{Sistem Perpajakan di Indonesia}

Reformasi perpajakan di Indonesia dimulai sejak tahun 1984 dengan diterapkannya sistem self assetsment. Menurut Waluyo (2011), self assessment system merupakan sistem pemungutan pajak yang memberi wewenang, kepercayaan, dan tanggung jawab kepada wajib pajak untuk menghitung, memperhitungkan, membayar, dan melaporkan sendiri besarnya pajak yang harus dibayar. Dalam kaitannya dengan akuntansi maka kepatuhan wajib pajak mengandung pengertian tersebut diatas. Dengan diterapkannya sistem tersebut, maka pemungutan pajak akan sangat bergantung pada kesadaran wajib pajak dalam membayar pajak, pengetahuan dan pemahaman akan peraturan perpajakan, dan pelayanan fiskus. Karena melalui sistem ini, setiap wajib pajak di wajibkan mengisi sendiri dan menyampaikan Surat Pemberitahuan (SPT) Tahunan dengan benar, lengkap, dan jelas.

\section{Administrasi Perpajakan}

Menurut Pandiangan (2008) mengemukakan bahwa administrasi perpajakan diupayakan untuk merealisasikan peraturan perpajakan dan penerimaan negara. Administrasi perpajakan dikatakan efektif bila mampu mengatasi masalah-masalah :

1. Wajib Pajak yang tidak terdaftar (unregistered taxpayers)

Dengan administrasi pajak yang efektif akan mampu mendeteksi dan menindak dengan menerapkan sanksi tegas bagi masyarakat yang telah memenuhi ketentuan menjadi Wajib Pajak tetapi belum terdaftar. Penambahan jumlah Wajib Pajak secara signifikan akan meningkatkan jumlah penerimaan pajak.

2. Wajib Pajak yang tidak menyampaikan laporan pajaknya

Administrasi perpajakan efektif akan dapat mengetahui penyebab Wajib Pajak tidak menyampaikan pajaknya melalui pemeriksaan pajak.

3. Penyelundup pajak (tax evaders)

Penyelundup pajak (tax evaders) yaitu Wajib Pajak yang melaporkan pajak lebih kecil dari yang seharusnya menurut ketentuan perundang-undangan akan lebih terdeteksi dengan dukungan adanya bank data tentang Wajib Pajak dan seluruh aktivitas usahanya sangat diperlukan.

4. Penunggak pajak (delinquent taxpayers)

Upaya pencairan tunggakan pajak dilakukan melalui pelaksanaan tindakan penagihan pajak secara intensif dalam setiap administrasi pajak yang baik akan ebih efektif melaksanakan upaya tersebut.

Dari pengertian tersebut bahwa administrasi perpajakan harus dilaksanakan oleh instansi atau badan yang berwenang dan bertanggung jawab dalam menyelenggarakan pungutan pajak. Kegiatan administrasi dilaksanakan oleh orang-orang dari instansi pemungut pajak yang secara hierarki mempunyai jenjang wewenang dan tanggung jawab pada level yang berbeda dari pejabat pajak sampai dengan staf baik yang terlibat langsung dalam teknis pemungutan (fungsi lini) maupun oleh orang-orang yang tugas dan fungsinya sebagai pendukung fungsi lini, yang disebut dengan fungsi staf.

\section{Perencanaan Pajak}


Menurut Zain (1997), perencanaan pajak merupakan tindakan penstruktruran yang terkait dengan konsekuensi potensi pajak, tekanan pada pendalian setiap transaksi yang ada konsekuensi pajaknya. Tujuannya adalah bagaimana pengeluaran tersebut dapat meminimalkan jumlah pajak yang dibayarkan kepada pemerintah melaui apa yang disebut dengan penghindaran pajak dan bukan penyelundupan pajak yang merupakan tindakan pidana yang tidapat ditolerir.

Manajemen Pajak dapat dibagi menjadi beberapa fungsi, yaitu :

Tax Planning

Zain (2005), Barusman \& Pratiwi (2016), Perencanaan pajak adalah langkah awal yang dapat dilakukan dalam manajemen pajak. Definisi dari Perencanaan Pajak adalah adalah proses mengorganisasi usaha wajib pajak atau kelompok wajib pajak sedemikian rupa sehingga utang pajaknya, baik pajak penghasilan maupun pajak-pajak lainnya, berada dalam posisi yang paling minimal, sepanjang hal ini dimungkinkan baik oleh ketentuan peraturan perundang-undangan perpajakan maupun secara komersial.

Kemudian menurut J R Cerepak dan D H Taylor tax planning dibagi menjadi 3,(tiga), yaitu:

a. Tax Saving (Penghematan Pajak)

b. Tax Avoidance (Penghindaran Pajak)

c. Tax Evasion (Penggelapan Pajak)

Tax Administration/Tax Compliance

Tax administration/tax complaince merupakan manajemen pajak dalam memenuhi kewajiban melaksanakan administrasi perpajakan dengan cara menghitung pajak secara benar, membayar pajak tepat waktu sehingga mengurangi resiko timbulnya denda.

\section{Tax Audit}

Mencakup strategi dalam menangani pemeriksaan pajak, menanggapi hasil pemeriksaan pajak maupun strategi dalam mengajukan surat keberatan atau surat banding. (Soedarsa et al., 2014)

\section{Pemeriksaan Pajak}

Pemeriksaan merupakan istilah yang sering digunakan dalam kaitannya dengan perpajakan, namun istilah yang lebih luas adalah auditing. Menurut Mulyadi dan Puradiredja (1998), Barusman \& Pratiwi (2016), mendefenisikan auditing sebagai suatu proses sistematik untuk memperoleh dan mengevaluasi bukti secara obyektif mengenai pernyataan-pernyataan tentang kegiatan dan kejadian ekonomi dengan tujuan untuk menetapkan tingkat kesesuaian antara pernyataan-pernyataan tersebut dengan kriteria yang telah ditetapkan, serta penyampaian hasil-hasilnya kepada pemakai yang berkepentingan. Sedangkan berdasarkan pasal 1 angka 25 Undang-undang Nomor 28 Tahun 2007 tentang Ketentuan Umum dan Tata Cara Perpajakan (UU KUP) disebutkan bahwa pemeriksaan adalah serangkaian kegiatan menghimpun dan mengolah data, keterangan dan/ atau bukti yang dilaksanakan secara objektif dan professional berdasarkan suatu standar pemeriksaan untuk menguji kepatuhan pemenuhan kewajiban perpajakan dan/ atau tujuan lain dalam rangka melaksanakan ketentuan peraturan perundang-undangan perpajakan. Berdasarkan pengertian tersebut maka pemeriksa pajak diberikan wewenang oleh undang-undang untuk melakukan tindakan pengujian apakah Wajib Pajak telah menyampaikan dan mengisi dengan benat surat pemberitahuan sesuai dengan kewajiban pajak yang seharusnya dibayar.

\section{Klasifikasi Lapangan Usaha (KLU)}

1. Berdasarkan Surat Edaran Direktur Jenderal Pajak Nomor : SE-03/PJ/2013 tentang Klasifikasi Lapangan Usaha (KLU) Wajib Pajak, dijelaskan bahwa :

2. KLU digunakan dalam tata administrasi perpajakan Direktorat Jenderal Pajak dan disusun menurut Kategori, Golongan Pokok, Golongan, Sub golongan dan Kelompok Kegiatan Ekonomi sebagaimana ditetapkan dalam Lampiran Keputusan Direktur Jenderal Pajak Nomor KEP-321/PJ/2012 tentang Perubahan Atas Keputusan Direktur Jenderal Pajak Nomor KEP-233/PJ/2012 tentang Klasifikasi Lapangan Usaha Wajib Pajak.

Setiap Wajib Pajak harus diberikan KLU dengan berpedoman pada hal-hal berikut :

a. KLU yang digunakan harus sesuai dengan kegiatan ekonomi yang sebenarnya dijalankan oleh Wajib Pajak;

b. KLU yang digunakan harus terdiri dari 5 (lima) digit angka sesuai dengan kode kelompok kegiatan ekonomi;

c. Penentuan KLU bagi Wajib Pajak yang memiliki lebih dari satu kegiatan ekonomi didasarkan pada kegiatan ekonomi yang dominan;

d. KLU untuk Wajib Pajak yang berstatus cabang harus mengikuti kode KLU pusatnya.

3. Proses penyesuaian, pengadministrasian dan pemutkhiran KLU dalam sistem administrasi perpajakan meliputi : 
a. Penyesuaian KLU atas Wajib Pajak yang terdaftar sebelum 1 Januari 2013 dilaksanakan sesuai dengan ketentuan sebagaimana diatur dalam Lampiran I Surat Edaran ini;

b. Pengadministrasian KLU atas Wajib Pajak yang terdaftar sejak 1 Januari 2013 dilaksanakan sesuai dengan ketentuan sebagaimana diatur dalam Lampiran II Surat Edaran ini;

c. Pemutakhiran KLU atas Wajib Pajak yang:

1) mengalami perubahan Kelompok Kegiatan Ekonomi, atau

2) memiliki Kelompok Kegiatan Ekonomi tidak sesuai dengan kondisi yang sebenarnya, dilaksanakan sesuai dengan ketentuan sebagaimana diatur dalam Surat Edaran Direktur Jenderal Pajak Nomor SE-60/PJ/2009 tentang Pembenahan Data Master File Wajib Pajak.

4. KLU digunakan untuk:

a. Tata Usaha Wajib Pajak, seperti data Kelompok Kegiatan Ekonomi Wajib Pajak dalam Master File Wajib Pajak, Kelompok Kegiatan Ekonomi pada Surat Pemberitahuan;

b. Dasar penyusunan Norma Penghitungan Penghasilan Neto;

c. Keperluan lainnya, seperti evaluasi penerimaan pajak sektoral, mapping potensi pajak sektoral, penentuan Wajib Pajak berisiko berbasis Benchmark Behavioral Model.

\section{Konsep Statistik Deskriptif}

Menurut Hakim (2010) disebutkan bahwa arti statistik adalah sebuah ilmu yang mempelajari teknik-teknik pengumpulan, pengorganisasian, pengaturan, analisis dan interprestasi atas informasi data. Dengan demikian dapat dikatakan bahwa statistik adalah suatu proses yans saling berurutan dan berkaitan, dari mulai langkah pengumpulan data sampai dengan langkah analisis dan interprestasi data.

Menurut Kuncoro (2007) disebutkan bahwa aplikasi statistik dalam bisnis dan ekonomi salah satunya digolongkan pada statistik deskriptif, yaitu menggunakan metode numerik dan grafis untuk mengenali pola sejumlah data, merangkum informasi yang terdapat dalam data tersebut, dan menyajikan informasi tersebut dalam bentuk yang diinginkan.

Statistika deskriptif adalah teknik statistik yang memberikan informasi hanya mengenai data yang dimiliki dan tidak bermaksud untuk menguji hipotesis dan kemudian menarik inferensi yang digeneralisasikan untuk data yang lebih besar atau populasi. Statistik deskriptif "hanya" dipergunakan untuk menyajikan dan menganalisis data agar lebih bermakna dan komunikatif dan disertai perhitungan-perhitungan "sederhana" yang bersifat lebih memperjelas keadaan dan atau karakteristik data yang bersangkutan (Burhan et al., 2000).

\section{Metodologi}

\section{Ruang Lingkup Penelitian}

Ruang lingkup penelitian ini berada di Kantor Wilayah DJP Bengkulu dan Lampung, sedangkan periode waktu penelitian adalah tahun 2016 sampai dengan tahun 2019. Data yang tersedia merupakan data kompilasi Kantor Wilayah DJP Bengkulu dan Lampung dan kantor pelayanan pajak (KPP) yang berada di lingkungan Kantor Wilayah DJP Bengkulu dan Lampung yang terdiri dari : KPP Pratama Tanjung Karang; KPP Pratama Kedaton; KPP Pratama Teluk Betung; KPP Pratama Natar; KPP Pratama Metro; KPP Pratama Kotabumi; KPP Pratama Bengkulu; KPP Pratama Curup dan KPP Pratama Argamakmur.

\section{Metode Penelitian}

Penelitian yang dilakukan menggunakan metode deskriptif kualitatif. Menurut Sugiyono (2005) bahwa metode deskriptif adalah suatu metode yang digunakan untuk menggambarkan atau menganalisis suatu hasil penelitian tetapi tidak digunakan untuk membuat kesimpulan yang lebih luas. Kemudian dalam proses pengolahan data digunakan statistika deskriptif.

\section{Obyek Penelitian}

Obyek penelitian adalah Laporan Hasil Pemeriksaan Pajak yang berasal dari Unit Pelaksana Pemeriksaan (UP2) Kantor Wilayah DJP Bengkulu dan Lampung beserta Unit Pelaksana Pemeriksaan (UP2) kantor pelayanan pajak (KPP) yang berada di lingkungan Kantor Wilayah DJP Bengkulu dan Lampung. Periode atau jangka waktu obyek penelitian dibatasi dari tahun 2016 sampai dengan tahun 2019. Sumber data sebagian besar diperoeh dari Bidang Pemeriksaan, Penagihan, Intelijen dan Penyidikan (PPIP) dan Bidang Data dan Pengawasan Potensi Perpajakan (DP3) serta data yang terdapat pada Sistem Informasi Lokal Kantor Wilayah DJP Bengkulu dan Lampung.

\section{Teknik Pengumpulan Data}

Adapun Teknik pengumpulan data dalam penelitian ini adalah sebagai berikut :

1. Studi Kepustakaan (Library Research) 
Studi kepustakaan dilakukan dengan cara mengumpulkan data melalui studi ke perpustakaan dengan membaca dan mempelajari literatur ilmiah, seperti buku, jurnal, majalah, karya tulis, skripsi, tesis, media online internet, intranet Direktorat Jenderal Pajak, Sistem Informasi Direktorat Jenderal Pajak, Sistem Informasi Kepegawaian, Keuangan dan Aktiva (SIKKA) serta dokumen-dokumen peraturan perpajakan dengan maksud menghimpun teori yang ada hubungannya dengan penulisan tesis ini. Data yang dikumpulkan adalah berupa data sekunder.

2. Studi Lapangan (Field Research)

Studi lapangan dijalankan dengan cara melakukan komunikasi dan mengajukan permohonan permintaan data kepada pihak-pihak yang dalam tugas dan jabatannya berkaitan dengan objek penelitian ini. Pihak yang terkait antara lain Bidang Pemeriksaan, Penagihan, Intelijen dan Penyidikan (PPIP) dan Bidang Data dan Pengawasan Potensi Perpajakan (DP3) pada Kantor Wilayah DJP Bengkulu dan Lampung.

\section{Sumber Data}

Data utama terkait penelitian ini berupa Laporan Hasil Pemeriksaan Pajak yang dibuat oleh Kelompok Fungsional Pemeriksa Pajak yang kemudian diolah oleh Seksi Administrasi dan Bimbingan Pemeriksaan yang ada pada Bidang Pemeriksaan, Penagihan, Intelijen dan Penyidikan (PPIP) dalam bentuk pencatatan pada buku pengawasan hasil pemeriksaan pajak. Berdasarkan buku pengawasan ini, Seksi Administrasi dan Bimbingan Pemeriksaan membuat laporan bulanan maupun laporan triwulanan terkait penyelesaian pemeriksaan.

Data yang terkait dalam penelitian ini adalah data terkait Wajib Pajak yang diperiksa di Kantor Wilayah DJP Bengkulu dan Lampung periode tahun 2016 sampai dengan tahun 2019 berupa : Laporan Hasil Pemeriksaan Pajak, laporan bulanan serta triwulan tentang kegiatan pemeriksaan pajak, profil Wajib Pajak Badan yang diperiksa, ruang lingkup dan jenis pemeriksaan pajak yang dilakukan terhadap Wajib Pajak Badan yang diperiksa, penerimaan pajak per-sektor usaha, penerimaan pajak dari hasil kegiatan pemeriksaan pajak persektor usaha dan jumlah kegiatan pemeriksaan yang telah dilakukan.

\section{Hasil dan Pembahasan}

\section{Karakteristik Wajib Pajak Badan Kantor Wilayah DJP Bengkulu Dan Lampung Berdasarkan Penenerimaan}

Berdasarkan data yang terdapat pada Bidang Data dan Pengawasan Potensi Perpajakan (DP3) Kantor Wilayah DJP Bengkulu dan Lampung dapat diketahui bahwa jumlah penerimaan pajak dari masing-masing sektor atau Klasifikasi Lapangan Usaha (KLU) Wajib Pajak Badan yang terdaftar di kantor pelayanan pajak (KPP) di lingkungan Kantor Wilayah DJP Bengkulu dan Lampung pada periode tahun 2016 sampai dengan tahun 2019 seperti pada tabel berikut 
Tabel 1. Penerimaan Sektoral WP Badan Kanwil DJP Bengkulu dan Lampung Periode Tahun 2016 2019 (dalam Rp)

\begin{tabular}{|c|c|c|c|c|c|c|}
\hline Kategori & Keterangan & Kode KLU & \multicolumn{4}{|c|}{ Realisasi } \\
\hline 1 & 2 & 3 & 4 & 5 & 6 & 7 \\
\hline A & PERTANIAN, KEHUTANAN DAN PERIKANAN & 01 s.d 03 & $203,953,375,794$ & $309,530,438,478$ & $337,058,493,243$ & $333,333,756,149$ \\
\hline B & PERTAMBANGAN DAN PENGGALIAN & 05 s.d. 09 & $93,945,987,635$ & $198,941,927,835$ & $285,338,644,089$ & $262,406,115,896$ \\
\hline C & INDUSTRI PENGOLAHAN & 10 s.d. 33 & $1,625,525,240,485$ & $1,701,817,187,184$ & $1,875,623,581,592$ & $1,445,484,556,741$ \\
\hline D & PENGADAAN LISTRIK, GAS, UAP/AIR PANAS DAN UDARA DINGIN & 35 & $75,589,811,810$ & $91,299,160,466$ & $115,466,867,362$ & $126,715,132,694$ \\
\hline$E$ & $\begin{array}{l}\text { PENGADAAN ARR, PENGELOLAAN SAMPAH DAN DAUR ULANG, } \\
\text { PEMBUANGAN DAN PEMBERSSHAN LLMBAH DAN SAMPAH }\end{array}$ & 36 s.d. 39 & $4,036,030,800$ & $19,599,578,786$ & $39,554,292,425$ & $25,020,726,409$ \\
\hline$F$ & KONSTRUKSI & 41 s.d. 43 & $890,461,381,991$ & $1,008,463,320,676$ & $1,071,029,488,185$ & $963,788,263,321$ \\
\hline G & $\begin{array}{l}\text { PERDAGANGAN BESAR DAN ECERAN; REPARASI DAN } \\
\text { PERAWATAN MOBIL DAN SEPEDA MOTOR }\end{array}$ & 45 s.d. 47 & $1,363,409,448,891$ & $1,549,949,213,903$ & $1,807,289,302,779$ & $1,815,918,517,117$ \\
\hline$H$ & TRANSPORTASI DAN PERGUDANGAN & 49 s.d. 53 & $210,230,813,013$ & $263,332,423,713$ & $319,558,864,085$ & $356,952,623,136$ \\
\hline | & PENYEDIAAN AKOMODASI DAN PENYEDIAAN MAKAN MINUM & 55 dan 56 & $14,295,117,318$ & $16,896,797,401$ & $19,645,209,175$ & $22,734,565,888$ \\
\hline J & INFORMASI DAN KOMUNIKASI & 58 s.d. 63 & $20,504,018,462$ & $23,150,476,075$ & $27,427,109,637$ & $25,413,037,757$ \\
\hline k & JASA KEUANGAN DAN ASURANSI & 64 s.d. 66 & $702,273,874,772$ & $725,010,465,393$ & $772,525,831,288$ & $855,556,441,411$ \\
\hline L & REAL ESTAT & 68 & $54,950,241,261$ & $48,377,156,779$ & $52,425,435,925$ & $57,647,654,145$ \\
\hline M & JASA PROFESIONAL, ILMIAH DAN TEKNIS & 69 s.d. 75 & $59,983,719,179$ & $108,512,085,505$ & $176,395,624,039$ & $167,618,287,207$ \\
\hline N & $\begin{array}{l}\text { JASA PERSEWAAN, KETENAGAKERJAAN, AGEN PERJALANAN } \\
\text { DAN PENUNJANG USAHA LAINNYA }\end{array}$ & 77 s.d. 82 & $22,728,759,142$ & $27,576,229,975$ & $34,842,688,543$ & $39,660,310,927$ \\
\hline 0 & ADMINISTRASIPEMERINTAHANDANJAMINANSOSIALWAJIB & 84 & $5,880,735,480$ & $4,722,792,971$ & $5,002,116,550$ & $5,173,299,247$ \\
\hline P & JASA PENDIDIKAN & 85 & $7,879,446,284$ & $8,470,361,004$ & $15,389,468,473$ & $18,830,726,854$ \\
\hline Q & JASA KESEHATAN DAN KEGIATAN SOSIAL & 86 s.d. 88 & $43,646,845,493$ & $51,463,262,778$ & $63,813,094,639$ & $73,807,966,060$ \\
\hline R & KEBUDAYAAN, HIBURAN DAN REKREASI & 90 s.d. 93 & $1,450,912,042$ & $2,217,228,741$ & $1,980,955,349$ & $2,667,313,772$ \\
\hline S & KEGIATAN JASA LAINNYA & 94 s.d. 96 & $3,817,680,036$ & $5,536,060,573$ & $5,711,437,902$ & $6,291,505,406$ \\
\hline $\mathrm{T}$ & $\begin{array}{l}\text { JASA PERORANGAN YANG MELAYANI RUMAH TANGGA; } \\
\text { KEGIATAN YANG MENGHASILKAN BARANG DAN JASA OLEH } \\
\text { RUMAHTANGGAYANG DIGUNAKAN SENDIRI UNTUK MEMENUHI } \\
\text { KEBUTUHAN }\end{array}$ & 97 dan 98 & $13,229,045$ & $18,839,435$ & $14,526,349$ & $2,571,817$ \\
\hline$U$ & $\begin{array}{l}\text { KEGIATAN BADAN INTERNASIONAL DAN BADAN EKSTRA } \\
\text { INTERNASIONAL LAINNYA }\end{array}$ & 99 & $14,625,700$ & 250,909 & $30,755,760$ & $52,250,080$ \\
\hline V & KLU ERROR & 00 & $956,908,096$ & $992,071,323$ & $949,884,499$ & $834,503,227$ \\
\hline & TOTAL & & $5,405,548,202,729$ & $6,165,877,329,903$ & $7,027,073,671,888$ & $6,005,910,125,261$ \\
\hline
\end{tabular}

Sumber: Bidang DP3 Kanwil DJP Bengkulu dan Lampung, diolah 
Penerimaan pajak dari suatu kantor pajak tidak terlepas dari jumlah Wajib Pajak. Adapun jumlah Wajib Pajak Badan efektif per-sektor usaha pada lingkungan Kantor Wilayah DJP Bengkulu dan Lampung periode tahun 2016 sampai dengan tahun 2019 dapat dilihat pada tabel berikut :

Tabel 2 Jumlah Wajib Pajak Badan Efektif Per-Sektor Usaha Kanwil DJP Bengkulu dan Lampung Periode Tahun 2016 - 2019

\begin{tabular}{|c|c|c|c|c|c|c|c|c|}
\hline Kategori | & Keterangan & Kode KLU & s.d. 2015 & +2016 & +2017 & +2018 & +2019 & Total S.D. 2019 \\
\hline$A$ & PERTANIAN, KEHUTANAN DAN PERIKANAN & 01 s.d 03 & 301 & 54 & 84 & 367 & 601 & 1,407 \\
\hline B & PERTAMBANGAN DAN PENGGALIAN & 05 s.d. 09 & 180 & 28 & 14 & 46 & 51 & 319 \\
\hline C & INDUSTRI PENGOLAHAN & 10 s.d. 33 & 918 & 74 & 106 & 189 & 227 & 1,514 \\
\hline D & PENGADAAN LISTRIK, GAS, UAP/ARR PANAS DAN UDARA DINGIN & 35 & 74 & 8 & 6 & 8 & 13 & 109 \\
\hline E & $\begin{array}{l}\text { PENGADAAN ARR, PENGELOLAAN SAMPAHDAN DAUR ULANG, } \\
\text { PEMBUANGAN DAN PEMBERSIHAN LIMBAH DANSAMPAH }\end{array}$ & 36 s.d. 39 & 55 & 1 & 9 & 93 & 129 & 287 \\
\hline $\mathrm{F}$ & KONSTRUKSI & 41 s.d. 43 & 5,211 & 668 & 460 & 560 & 742 & 7,641 \\
\hline G & $\begin{array}{l}\text { PERDAGANGAN BESAR DAN ECERAN; REPARASI DAN } \\
\text { PERAWATAN MOBIL DAN SEPEDA MOTOR }\end{array}$ & 45 s.d. 47 & 6,626 & 757 & 826 & 1,150 & 1,092 & 10,451 \\
\hline H & TRANSPORTASI DAN PERGUDANGAN & 49 s.d. 53 & 670 & 97 & 186 & 211 & 170 & 1,334 \\
\hline I & PENYEDIAAN AKOMODASI DAN PENYEDIAAN MAKAN MINUM & 55 dan 56 & 225 & 41 & 37 & 62 & 102 & 467 \\
\hline J & INFORMASI DAN KOMUNIKASI & 58 s.d. 63 & 335 & 71 & 105 & 183 & 196 & 890 \\
\hline K & JASA KEUANGAN DAN ASURANSI & 64 s.d. 66 & 1,187 & 68 & 117 & 163 & 154 & 1,689 \\
\hline L & REAL ESTAT & 68 & 189 & 28 & 34 & 58 & 64 & 373 \\
\hline M & JASA PROFESIONAL, ILMIAH DAN TEKNIS & 69 s.d. 75 & 519 & 92 & 67 & 108 & 108 & 894 \\
\hline N & $\begin{array}{l}\text { JASA PERSEWAAN, KETENAGAKERAAAN, AGEN PERJALANAN } \\
\text { DAN PENUNJANG USAHA LAINNYA }\end{array}$ & 77 s.d. 82 & 445 & 78 & 186 & 211 & 289 & 1,209 \\
\hline 0 & ADMINISTRAS PEMERINTAHAN DAN JAMINAN SOSIAL WAJIB & 84 & 32 & 1 & 1 & 5 & 1 & 40 \\
\hline p & JASA PENDIDIKAN & 85 & 3,794 & 888 & 669 & 655 & 1,164 & 7,170 \\
\hline Q & JASA KESEHATAN DAN KEGIATAN SOSIAL & 86 s.d. 88 & 393 & 78 & 74 & 104 & 150 & 799 \\
\hline$R$ & KEBUDAYAAN, HIBURAN DAN REKREASI & 90 s.d. 93 & 101 & 21 & 30 & 82 & 122 & 356 \\
\hline S & KEGIATAN JASA LAINNYA & 94 s.d. 96 & 691 & 105 & 255 & 531 & 841 & 2,423 \\
\hline T & $\begin{array}{l}\text { JASA PERORANGAN YANG MELAYANI RUMAH TANGGA; } \\
\text { KEGIATAN YANG MENGHASILKAN BARANG DAN JASA OLEH } \\
\text { RUMAHTANGGA YANG DGGUNAKAN SENDRI UNTUK MEMENUHI } \\
\text { KEBUTUHAN }\end{array}$ & 97 dan 98 & 14 & & & & 1 & 15 \\
\hline U & $\begin{array}{l}\text { KEGIATAN BADAN INTERNASIONAL DAN BADAN EKSTRA } \\
\text { INTERNASIONAL LAINNYA }\end{array}$ & 99 & 5 & & & 1 & 2 & 8 \\
\hline V & KLUERROR & 00 & 508 & 4 & & 174 & 667 & 1,353 \\
\hline & TOTAL & & 22,473 & 3,162 & 3,266 & 4,961 & 6,886 & 40,748 \\
\hline
\end{tabular}

Sumber : Bidang DP3 Kanwil DJP Bengkulu dan Lampung, diolah 
Berdasarkan uraian di atas maka dapat diketahui rata-rata penerimaan per-sektor usaha/ KLU. Rata-rata penerimaan per-sektor usaha/ KLU ini diperoleh dari perhitungan : Jumlah penerimaan pajak per-sektor usaha dibagi jumlah Wajib Pajak Badan Efektif sektor usaha tersebut. Besarnya rata-rata penerimaan per-sektor usaha dapat dilihat pada tabel berikut :

Tabel 3. Penerimaan Sektoral Rata-Rata WP Badan Kanwil DJP Bengkulu dan Lampung Periode Tahun 2016 - 2019 (dalam Rp)

\begin{tabular}{|c|c|c|c|c|c|c|}
\hline Kategori & Keterangan & Kode KLU & \multicolumn{4}{|c|}{ Realisasi } \\
\hline & & & & & & \\
\hline 1 & 2 & 3 & 4 & 5 & 6 & 7 \\
\hline A & PERTANIAN, KEHUTANAN DAN PERIKANAN & 01 s.d 03 & $574,516,552$ & $705,080,725$ & $418,186,716$ & $236,910,985$ \\
\hline B & PERTAMBANGAN DAN PENGGALIAN & 05 s.d. 09 & $451,663,402$ & $896,134,810$ & $1,064,696,433$ & $822,589,705$ \\
\hline$C$ & INDUSTRI PENGOLAHAN & 10 s.d. 33 & $1,638,634,315$ & $1,549,924,578$ & $1,457,360,980$ & $954,745,414$ \\
\hline D & PENGADAAN LISTRIK, GAS, UAP/AIR PANAS DAN UDARA DINGIN & 35 & $921,826,973$ & $1,037,490,460$ & $1,202,779,868$ & $1,162,524,153$ \\
\hline$E$ & $\begin{array}{l}\text { PENGADAAN AIR, PENGELOLAAN SAMPAH DAN DAUR ULANG, } \\
\text { PEMBUANGAN DAN PEMBERSIHAN LIMBAH DAN SAMPAH }\end{array}$ & 36 s.d. 39 & $72,071,979$ & $301,531,981$ & $250,343,623$ & $87,180,231$ \\
\hline $\mathrm{F}$ & KONSTRUKSI & 41 s.d. 43 & $151,464,770$ & $159,088,708$ & $155,244,164$ & $126,133,787$ \\
\hline G & $\begin{array}{l}\text { PERDAGANGAN BESAR DAN ECERAN; REPARASI DAN } \\
\text { PERAWATAN MOBIL DAN SEPEDA MOTOR }\end{array}$ & 45 s.d. 47 & $184,668,759$ & $188,810,965$ & $193,107,095$ & $173,755,480$ \\
\hline$H$ & TRANSPORTASI DAN PERGUDANGAN & 49 s.d. 53 & $274,094,932$ & $276,319,437$ & $274,535,107$ & $267,580,677$ \\
\hline I & PENYEDIAAN AKOMODASI DAN PENYEDIAAN MAKAN MINUM & 55 dan 56 & $53,741,043$ & $55,765,008$ & $53,822,491$ & $48,682,154$ \\
\hline J & INFORMASI DAN KOMUNIKASI & 58 s.d. 63 & $50,502,509$ & $45,304,258$ & $39,520,331$ & $28,553,975$ \\
\hline K & JASA KEUANGAN DAN ASURANSI & 64 s.d. 66 & $559,580,777$ & $528,433,284$ & $503,274,157$ & $506,546,146$ \\
\hline L & REAL ESTAT & 68 & $253,226,918$ & $192,737,676$ & $169,661,605$ & $154,551,352$ \\
\hline M & JASA PROFESIONAL, ILMIAH DAN TEKNIS & 69 s.d. 75 & $98,173,026$ & $160,047,324$ & $224,421,914$ & $187,492,491$ \\
\hline N & $\begin{array}{l}\text { JASA PERSEWAAN, KETENAGAKERJAAN, AGEN PERJALANAN } \\
\text { DAN PENUNJANG USAHA LAINNYA }\end{array}$ & 77 s.d. 82 & $43,458,430$ & $38,894,542$ & $37,872,488$ & $32,804,227$ \\
\hline 0 & ADMINISTRASI PEMERINTAHAN DAN JAMINAN SOSIAL WAJIB & 84 & $178,204,105$ & $138,905,676$ & $128,259,399$ & $129,332,481$ \\
\hline$p$ & JASA PENDIDIKAN & 85 & $1,682,923$ & $1,582,949$ & $2,562,349$ & $2,626,322$ \\
\hline$Q$ & JASA KESEHATAN DAN KEGIATAN SOSIAL & 86 s.d. 88 & $92,668,462$ & $94,428,005$ & $98,325,261$ & $92,375,427$ \\
\hline$R$ & KEBUDAYAAN, HIBURAN DAN REKREASI & 90 s.d. 93 & $11,892,722$ & $14,587,031$ & $8,465,621$ & $7,492,454$ \\
\hline$S$ & KEGIATAN JASA LAINNYA & 94 s.d. 96 & $4,796,080$ & $5,267,422$ & $3,610,264$ & $2,596,577$ \\
\hline $\mathrm{T}$ & $\begin{array}{l}\text { JASA PERORANGAN YANG MELAYANI RUMAH TANGGA; } \\
\text { KEGIATAN YANG MENGHASILKAN BARANG DAN JASA OLEH } \\
\text { RUMAHTANGGAYANG DIGUNAKANSENDIRI UNTUKMEMENUH } \\
\text { KEBUTUHAN }\end{array}$ & 97 dan 98 & 944,932 & $1,345,674$ & $1,037,596$ & 171,454 \\
\hline U & $\begin{array}{l}\text { KEGIATAN BADAN INTERNASIONAL DAN BADAN EKSTRA } \\
\text { INTERNASIONAL LAINNYA }\end{array}$ & 99 & $2,437,617$ & 41,818 & $5,125,960$ & $6,531,260$ \\
\hline V & KLU ERROR & 00 & $1,868,961$ & $1,937,639$ & $1,384,671$ & 616,780 \\
\hline & Total & & $5,622,120,187$ & 6,393,659,972 & $6,293,598,094$ & $5,031,793,533$ \\
\hline
\end{tabular}

Sumber : Bidang DP3 Kanwil DJP Bengkulu dan Lampung, diolah

Hasil Pemeriksaan Pajak 
Adapun rata-rata penerimaan hasil pemeriksaan pajak per-sektor usaha dapat digunakan sebagai sarana untuk mengetahui sektor usaha yang potensial sesuai hasil pemeriksaan pajak yang memberi konstribusi besar bagi penerimaan pajak di lingkungan Kantor Wilayah DJP Bengkulu dan Lampung. Sektor usaha yang potensial tersebut dapat dilihat pada tabel berikut :

Tabel 4. Rata-Rata Penerimaan Hasil Pemeriksaan PerSektor Usaha Wajib Pajak Badan Kantor Wilayah DJP Bengkulu dan Lampung Periode Tahun 2016 - 2019

\begin{tabular}{|c|c|c|c|c|c|c|}
\hline Kategori & Keterangan & Kode KLU & \multicolumn{4}{|c|}{ Realisasi } \\
\hline 1 & 2 & 3 & 4 & 5 & 6 & 7 \\
\hline A & PERTANIAN, KEHUTANAN DAN PERIKANAN & 01 s.d 03 & $4,038,897$ & $70,054,356$ & $55,258,355$ & $375,816,899$ \\
\hline$B$ & PERTAMBANGAN DAN PENGGALIAN & 05 s.d. 09 & $2,631,465$ & $55,203,660$ & $1,365,370,391$ & $236,846,600$ \\
\hline$c$ & INDUSTRI PENGOLAHAN & 10 s.d. 33 & $72,311,493$ & $50,865,637$ & $166,993,288$ & 434,033,959 \\
\hline$D$ & PENGADAAN LISTRIK, GAS, UAP/AIRPANASDANUDARADINGIN & 35 & & & 500,000 & $15,857,143$ \\
\hline $\mathrm{E}$ & $\begin{array}{l}\text { PENGADAAN AIR, PENGELOLAAN SAMPAH DAN DAUR ULANG, } \\
\text { PEMBUANGAN DAN PEMBERSIHAN LIMBAH DAN SAMPAH }\end{array}$ & 36 s.d. 39 & $88,418,427$ & $1,937,209$ & & $158,103,178$ \\
\hline $\mathrm{F}$ & KONSTRUKSI & 41 s.d. 43 & $34,467,882$ & $59,106,167$ & $84,688,029$ & $102,155,110$ \\
\hline G & $\begin{array}{l}\text { PERDAGANGAN BESAR DAN ECERAN; REPARASI DAN } \\
\text { PERAWATAN MOBIL DAN SEPEDA MOTOR }\end{array}$ & 45 s.d. 47 & $41,752,020$ & $82,125,504$ & $61,933,209$ & $173,734,008$ \\
\hline$H$ & TRANSPORTASI DAN PERGUDANGAN & 49 s.d. 53 & $2,754,175$ & $9,082,152$ & $9,185,008$ & $36,583,669$ \\
\hline I & PENYEDIAAN AKOMODASI DAN PENYEDIAAN MAKAN MINUM & 55 dan 56 & $30,686,120$ & $8,572,510$ & $137,309,720$ & $148,643,839$ \\
\hline $\mathrm{J}$ & INFORMASI DAN KOMUNIKASI & 58 s.d. 63 & $2,081,748$ & $30,932,532$ & $33,832,050$ & \\
\hline k & JASA KEUANGAN DAN ASURANSI & 64 s.d. 66 & $18,671,490$ & $10,636,384$ & $106,800,561$ & $72,204,456$ \\
\hline $\mathrm{L}$ & REAL ESTAT & 68 & $41,533,092$ & $40,885,331$ & $6,967,280$ & $2,455,206$ \\
\hline M & JASA PROFESIONAL, ILMIAH DAN TEKNIS & 69 s.d. 75 & $26,115,809$ & 950,620 & $1,023,342$ & $4,256,851$ \\
\hline N & $\begin{array}{l}\text { JASA PERSEWAAN, KETENAGAKERJAAN, AGEN PERJALANAN } \\
\text { DAN PENUNJANG USAHA LAINNYA }\end{array}$ & 77 s.d. 82 & $6,046,251$ & $38,178,286$ & $85,569,565$ & $143,228,384$ \\
\hline 0 & ADMINISTRASI PEMERINTAHAN DAN JAMINAN SOSIAL WAJIB & 84 & & $2,097,733$ & $3,640,881$ & 893 \\
\hline$p$ & JASA PENDIDIKAN & 85 & $3,530,700$ & 269,231 & $113,528,433$ & $2,851,331$ \\
\hline$Q$ & JJASA KESEHATAN DAN KEGIATAN SOSIAL & 86 s.d. 88 & & $5,835,277$ & $86,611,591$ & $77,189,026$ \\
\hline$R$ & KEBUDAYAAN, HIBURAN DAN REKREASI & 90 s.d. 93 & & $16,787,100$ & - & \\
\hline$S$ & KEGIATAN JASA LAINNYA & 94 s.d. 96 & $4,728,463$ & $4,267,169$ & $12,330,169$ & $23,263,907$ \\
\hline T & $\begin{array}{l}\text { JASA PERORANGAN YANG MELAYANI RUMAH TANGGA; } \\
\text { KEGIATAN YANG MENGHASIKKAN BARANG DAN JASA OLEH } \\
\text { RUMAHTANGGAYANG DIGUNAKANSENDIRI UNTUKMEMENUH } \\
\text { KEBUTUHAN }\end{array}$ & 97 dan 98 & & & $75,326,755$ & \\
\hline U & $\begin{array}{l}\text { KEGIATAN BADAN INTERNASIONAL DAN BADAN EKSTRA } \\
\text { INTERNASIONAL LAINNYA }\end{array}$ & 99 & & & & \\
\hline V & KLU ERROR & 00 & & & 39,846 & 2,923 \\
\hline & N/A & & $2,344,815,799$ & $44,125,312$ & $14,600,967$ & $174,051,053$ \\
\hline & TOTAL & & $2,724,583,831$ & $531,912,172$ & $2,421,509,438$ & $2,181,278,435$ \\
\hline
\end{tabular}

Sumber : Seksi Administrasi dan Bimbingan Pemeriksaan Kanwil DJP Bengkulu dan Lampung, diolah 
Adapun rata-rata penerimaan hasil Pemeriksaan Khusus Wajib Pajak Badan per-sektor usaha untuk tahun 2016 sampai tahun 2019 dapat dilihat pada tabel berikut:

Tabel 5. Rata-Rata Hasil Pemeriksaan Khusus Per-Sektor Usaha Wajib Pajak Badan Kantor Wilayah DJP Bengkulu dan Lampung Periode Tahun 2016 - 2019

\begin{tabular}{|c|c|c|c|c|c|c|}
\hline Kategori & Keterangan & Kode KLU & \multicolumn{4}{|c|}{ Realisasi } \\
\hline 1 & 2 & 3 & 4 & 5 & 6 & 7 \\
\hline A & PERTANIAN, KEHUTANAN DAN PERIKANAN & 01 s.d 03 & $1,586,770$ & $4,830,251$ & $58,718,267$ & $495,831,967$ \\
\hline B & PERTAMBANGAN DAN PENGGALIAN & 05 s.d. 09 & $7,017,241$ & $312,820,738$ & $2,706,528,100$ & $38,703,535$ \\
\hline C & INDUSTRI PENGOLAHAN & 10 s.d. 33 & $123,065,878$ & $61,625,050$ & $292,381,532$ & $318,342,572$ \\
\hline D & PENGADAAN LISTRIK, GAS, UAP/AIR PANAS DAN UDARA DINGI & 35 & & & 500,000 & \\
\hline$E$ & $\begin{array}{l}\text { PENGADAAN AIR, PENGELOLAAN SAMPAH DAN DAUR ULANG, } \\
\text { PEMBUANGAN DAN PEMBERSIHAN LIMBAH DAN SAMPAH }\end{array}$ & 36 s.d. 39 & & $5,165,892$ & & $1,185,773,837$ \\
\hline $\mathrm{F}$ & KONSTRUKSI & 41 s.d. 43 & $45,621,875$ & $53,382,317$ & $54,895,441$ & $27,421,347$ \\
\hline G & $\begin{array}{l}\text { PERDAGANGAN BESAR DAN ECERAN; } \\
\text { PERAWATAN MOBIL DAN SEPEDA MOTOR }\end{array}$ & 45 s.d. 47 & $85,779,520$ & $116,237,948$ & $48,447,405$ & $147,527,318$ \\
\hline$H$ & TRANSPORTASI DAN PERGUDANGAN & 49 s.d. 53 & 25,000 & $7,508,451$ & $8,617,537$ & $26,873,357$ \\
\hline 1 & PENYEDIAAN AKOMODASI DAN PENYEDIAAN MAKAN MINUM & 55 dan 56 & & $15,716,269$ & $131,251,262$ & $265,281,898$ \\
\hline J & INFORMASI DAN KOMUNIKASI & 58 s.d. 63 & & $30,932,532$ & $27,967,249$ & \\
\hline K & JASA KEUANGAN DAN ASURANSI & 64 s.d. 66 & $17,265,126$ & $17,044,611$ & $49,056,195$ & $2,208,392$ \\
\hline $\mathrm{L}$ & REAL ESTAT & 68 & $25,871,647$ & $46,181,896$ & $7,523,427$ & \\
\hline M & JASA PROFESIONAL, ILMIAH DAN TEKNIS & 69 s.d. 75 & $43,247,101$ & 835,568 & 966,257 & 724,245 \\
\hline N & $\begin{array}{l}\text { JASA PERSEWAAN, KETENAGAKERJAAN, AGEN PERJALANAN } \\
\text { DAN PENUNJANG USAHA LAINNYA }\end{array}$ & 77 s.d. 82 & & $37,561,923$ & $329,808,545$ & $5,026,400$ \\
\hline 0 & ADMINISTRASI PEMERINTAHAN DAN JAMINAN SOSIAL WAJIB & 84 & - & $7,973,324$ & $11,327,186$ & \\
\hline$p$ & JASA PENDIDIKAN & 85 & - & 214,286 & $358,570,009$ & 240,000 \\
\hline 0 & JASA KESEHATAN DAN KEGIATAN SOSIAL & 86 s.d. 88 & & $12,309,999$ & $129,917,386$ & $105,599,676$ \\
\hline$R$ & KEBUDAYAAN, HIBURAN DAN REKREASI & 90 s.d. 93 & & $16,787,100$ & - & \\
\hline$S$ & KEGIATAN JASA LAINNYA & 94 s.d. 96 & & 614,484 & - & \\
\hline $\mathrm{T}$ & $\begin{array}{l}\text { JASA PERORANGAN YANG MELAYANI RUMAH TANGGA; } \\
\text { KEGIATAN YANG MENGHASILKAN BARANG DAN JASA OLEH } \\
\text { RUMAH TANGGA YANG DIGUNAKAN SENDIRI UNTUK } \\
\text { MEMENUHI KEBUTUHAN }\end{array}$ & 97 dan 98 & & & & \\
\hline U & $\begin{array}{l}\text { KEGIATAN BADAN INTERNASIONAL DAN BADAN EKSTRA } \\
\text { INTERNASIONAL LAINNYA }\end{array}$ & 99 & & & & \\
\hline V & KLU ERROR & 00 & & & - & \\
\hline & N/A & & - & $154,178,401$ & $10,185,290$ & 150,092 \\
\hline & TOTAL & & $349,480,157$ & $901,921,039$ & $4,226,661,090$ & $2,619,704,635$ \\
\hline
\end{tabular}

Sumber : Seksi Administrasi dan Bimbingan Pemeriksaan Kanwil DJP Bengkulu dan Lampung, diolah

Sedangkan rata-rata penerimaan hasil pemeriksaan Pemeriksaan Rutin dan Pemeriksaan Tujuan Lain per-sektor usaha Wajib Pajak Badan di Kantor Wilayah DJP Bengkulu dan Lampung dapat dilihat pada tabel berikut : 
Tabel 6. Rata-Rata Penerimaan Hasil Pemeriksaan Rutin \& Tujuan Lain Per-Sektor Usaha Wajib Pajak Badan Kantor Wilayah DJP Bengkulu dan Lampung Periode Tahun 2016 - 2019

\begin{tabular}{|c|c|c|c|c|c|c|}
\hline Kategori & Keterangan & Kode KLU & \multicolumn{4}{|c|}{ Realisasi } \\
\hline & & & & & & \\
\hline 1 & 2 & 3 & 4 & 5 & 6 & 7 \\
\hline A & PERTANIAN, KEHUTANAN DAN PERIKANAN & 01 s.d 03 & $4,992,502$ & $108,002,927$ & $50,911,285$ & $307,236,860$ \\
\hline$B$ & PERTAMBANGAN DAN PENGGALIAN & 05 s.d. 09 & - & - & $633,829,822$ & $522,503,998$ \\
\hline C & INDUSTRI PENGOLAHAN & 10 s.d. 33 & $46,283,603$ & $39,684,286$ & $25,425,916$ & $515,190,605$ \\
\hline D & PENGADAAN LISTRIK, GAS,UAP/AIRPANASDANUDARADINGIN & 35 & - & - & - & $15,857,143$ \\
\hline $\mathrm{E}$ & $\begin{array}{l}\text { PENGADAAN AIR, PENGELOLAAN SAMPAH DAN DAUR ULANG, } \\
\text { PEMBUANGAN DAN PEMBERSIHAN LIMBAH DAN SAMPAH }\end{array}$ & 36 s.d. 39 & $101,049,631$ & - & - & \\
\hline $\mathrm{F}$ & KONSTRUKSI & 41 s.d. 43 & $30,006,285$ & $66,088,007$ & $134,196,300$ & $136,647,616$ \\
\hline G & $\begin{array}{l}\text { PERDAGANGAN BESAR DAN ECERAN; REPARASI DAN } \\
\text { PERAWATAN MOBIL DAN SEPEDA MOTOR }\end{array}$ & 45 s.d. 47 & $22,366,777$ & $40,538,222$ & $86,101,587$ & $189,937,068$ \\
\hline H & TRANSPORTASI DAN PERGUDANGAN & 49 s.d. 53 & $2,968,228$ & $11,101,734$ & $9,962,365$ & $39,251,337$ \\
\hline 1 & PENYEDIAAN AKOMODASI DAN PENYEDIAAN MAKAN MINUM & 55 dan 56 & $46,029,180$ & - & $161,543,553$ & $32,005,781$ \\
\hline J & INFORMASI DAN KOMUNIKASI & 58 s.d. 63 & $2,081,748$ & - & - & - \\
\hline K & JASA KEUANGAN DAN ASURANSI & 64 s.d. 66 & $19,374,672$ & 131,092 & $239,721,554$ & $136,486,557$ \\
\hline $\mathrm{L}$ & REAL ESTAT & 68 & $54,957,187$ & $21,212,376$ & $5,090,282$ & $3,949,679$ \\
\hline M & JASA PROFESIONAL, ILMIAH DAN TEKNIS & 69 s.d. 75 & $12,655,509$ & $1,348,879$ & $1,102,081$ & $5,066,407$ \\
\hline N & $\begin{array}{l}\text { JASA PERSEWAAN, KETENAGAKERJAAN, AGEN PERJALANAN } \\
\text { DAN PENUNJANG USAHA LAINNYA }\end{array}$ & 77 s.d. 82 & $9,069,377$ & $38,794,650$ & $24,509,820$ & $189,295,712$ \\
\hline 0 & ADMINISTRASI PEMERINTAHAN DAN JAMINAN SOSIAL WAJIB & 84 & - & 289,859 & - & 917 \\
\hline$P$ & JASA PENDIDIKAN & 85 & $3,530,700$ & 333,333 & 432,320 & $3,667,372$ \\
\hline Q & JASA KESEHATAN DAN KEGIATAN SOSIAL & 86 s.d. 88 & - & 42,105 & - & $72,302,263$ \\
\hline$R$ & KEBUDAYAAN, HIBURAN DAN REKREASI & 90 s.d. 93 & - & - & - & \\
\hline$S$ & KEGIATAN JASA LAINNYA & 94 s.d. 96 & $5,910,579$ & $11,432,051$ & $41,141,431$ & $27,676,027$ \\
\hline $\mathrm{T}$ & $\begin{array}{l}\text { JASA PERORANGAN YANG MELAYANI RUMAH TANGGA; } \\
\text { KEGIATAN YANG MENGHASILKAN BARANG DAN JASA OLEH } \\
\text { RUMAHTANGGAYANG DIGUNAKAN SENDIRI UNTUKMEMENUHI } \\
\text { KEBUTUHAN }\end{array}$ & 97 dan 98 & - & - & $75,326,755$ & \\
\hline$U$ & $\begin{array}{l}\text { KEGIATAN BADAN INTERNASIONAL DAN BADAN EKSTRA } \\
\text { INTERNASIONAL LAINNYA }\end{array}$ & 99 & - & - & - & \\
\hline V & KLU ERROR & 00 & - & - & - & \\
\hline & $\mathrm{N} / \mathrm{A}$ & & $2,344,815,799$ & $16,092,876$ & $8,582,386$ & $174,020,265$ \\
\hline & TOTAL & & $2,706,091,776$ & $355,092,397$ & $1,497,877,457$ & $2,371,095,606$ \\
\hline
\end{tabular}

Sumber : Seksi Administrasi dan Bimbingan Pemeriksaan Kanwil DJP Bengkulu dan Lampung, diolah

\section{Penelitian Berdasarkan Administrasi Perencanaan Kegiatan Pemeriksaan Pajak}

Administrasi perencanaan kegiatan pemeriksaan pajak dilakukan oleh Unit Pelaksana Pemeriksaan (UP2) Direktorat Jenderal Pajak yaitu Kantor Wilayah DJP Bengkulu dan Lampung beserta Kantor Pelayanan Pajak yang berada di bawahnya. Guna mengoptimalkan hasil dari kegiatan pemeriksaan pajak yang tercermin dari perolehan penerimaan perpajakan maka secara normatif kegiatan pemeriksaan pajak tersebut haruslah memenuhi beberapa persyaratan. Persayaratan tersebut dibuat berdasarkan pengelompokan hasil pemeriksaan pajak. Sesuai uraian di atas telah diketahui bahwa atas hasil pemeriksaan pajak dapat dikeompokan berdasarkan 
1. Ruang Lingkup Pemeriksaan, yang dapat dibedakan atas pemeriksaan Seluruh Jenis Pajak (All Taxes), Pemeriksaan Beberapa Jenis Pajak, dan Pemeriksaan Satu Jenis Pajak (Single Tax).

2. Jenis Pemeriksaan, dapat dibedakan atas Pemeriksaan Rutin, Pemeriksaan Khusus dan Pemeriksaan Tujuan Lain.

Berdasarkan pengelompokan hasil pemeriksaan pajak ini maka dapat dilihat bahwa yang menjadi persyaratan tersebut adalah terkait masalah jangka waktu pemeriksaan, luas sempitnya pemeriksaan, dan dasar pelaksanaan pemeriksaan tersebut.

Untuk dapat mengoptimalkan kegiatan pemeriksaan pajak dalam rangka menguji kepatuhan pemenuhan kerajiban perpajakan dari Wajib Pajak maka pemeriksaan pajak memerlukan waktu yang cukup. Oleh sebab itu perlu dibuat administrasi perencanaan kegiatan pemeriksaan yang sesuai pula. Berdasarkan Pasal 15 ayat 2 Peraturan Menteri Keuangan Nomor : 184/PMK.03/2015 tanggal 30 September 2015 dijelaskan bahwa Pemeriksaan Lapangan dilakukan dalam jangka waktu paling lama 6 (enam) bulan sedangkan Pemeriksaan Kantor dilakukan dalam jangka waktu paling lama 4 (empat) bulan sehingga yang dipilih sebaiknya adalah Pemeriksaan Lapangan. Hal ini dimaksudkan untuk memberikan waktu yang lebih panjang kepada Tim Pemeriksa sehingga bisa lebih fokus dan lebih detail dalam melakukan pemeriksaan.

Selain itu dengan Pemeriksaan Lapangan ini, Pemeriksa Pajak dapat melakukan pemeriksaan langsung ke tempat usaha Wajib Pajak baik yang berada di wilayah kantor pelayanan pajak dimana Wajib Pajak tersebut terdaftar maupun yang berada di luar wilayah kantor pelayanan pajak dimana Wajib Pajak tersebut terdaftar. Hal ini bisa terjadi bila Wajib Pajak tersebut ternyata memiliki kegiatan usaha satu atau lebih dari satu tempat usaha dan terpencar-pencar. Juga dengan Pemeriksaan Lapangan ini Pemeriksa Pajak dapat dapat melakukan permintaan keterangan kepada rekan bisnis (klien, vendor, supplier, distributor, dll) atau pihak ketiga lainnya (bank, kantor konsultan pajak, kantor akuntan publik, dll) terkait Wajib Pajak yang diperiksa bilamana dirasakan perlu untuk pelaksanaan klarifikasi maupun konfirmasi kebenaran data yang dilaporkan oleh Wajib Pajak. Hal yang berbeda jika pemeriksaan pajak dilakukan melalui Pemeriksaan Kantor dimana pemeriksaan tersebut hanya dilakukan di kantor Direktorat Jenderal Pajak dan tidak bisa melakukan pemeriksaan ke tempat usaha maupun tempat-tempat terkait usaha Wajib Pajak.

Selain itu pemeriksaan pajak yang dilakukan ruang lingkupnya harus menyeluruh, maksudnya pemeriksaan pajak dilakukan terhadap seluruh jenis pajak (All Taxes) sesuai dengan kewajiban perpajakan yang melekat pada Wajib Pajak tersebut sehingga tidak terdapat objek pajak yang terlewat dari pengitungan pajak yang terutang. Persyaratan pemeriksaan seluruh jenis pajak (All Taxes) ini penting karena dengan pemeriksaan seluruh jenis pajak maka semua kewajiban perpajakan dapat diperiksa secara terpadu (integrated) berdasarkan laporan keuangan yang disampaikan Wajib Pajak.

Persayaratan berikutnya adalah menyangkut dasar pelaksanaan kegiatan pemeriksaan pajak tersebut. Sesuai dengan penjelasan di atas disebutkan bahwa Pemeriksaan Rutin adalah pemeriksaan yang dilakukan terhadap Wajib Pajak sehubungan dengan pemenuhan hak dan/atau pelaksanaan kewajiban perpajakannya atau karena diwajibkan oleh Undang-undang Ketentuan Umum dan Tata Cara Perpajakan (KUP), sedangkan Pemeriksaan Khusus adalah pemeriksaan yang dilakukan berdasarkan hasil analisis risiko terhadap ketidakpatuhan Wajib Pajak. Pemeriksaan Khusus merupakan pemeriksaan yang telah didasari oleh analisis risiko sehingga tentunya sudah ada perhitungan potensi pajak yang mungkin diperoleh dari hasil pemeriksaan sesuai dengan data yang telah diperoleh. Sementara itu Pemeriksaan Tujuan Lain adalah pemeriksaan yang dilakukan dalam rangka melaksanakan ketentuan peraturan perundang-undangan perpajakan.

Oleh sebab itu sesuai dengan uraian di atas, maka dapat ditarik kesimpulan terkait penelitian berdasarkan administrasi perencanaan kegiatan pemeriksaan pajak di lingkungan Kantor Wilayah DJP Bengkulu dan Lampung guna mengoptimalkan penerimaan dari pemeriksaan pajak adalah sebaiknya lebih mengedepankan penerapan kebijakan Pemeriksaan Khusus bagi Wajib Pajak Badan dibandingkan dengan Pemeriksaan Rutin dan Pemeriksaan Tujuan Lain karena dengan Pemeriksaan Khusus maka pemeriksaan pajak yang dilakukan otomatis masuk dalam kriteria Pemeriksaan Lapangan dengan ruang lingkup seluruh jenis pajak (All Taxes).

\section{Pemetaan (Mapping) Berdasarkan Penerimaan Sektoral Wajib Pajak}

Berdasarkan data penerimaan sektoral Wajib Pajak Badan pada Kantor Wilayah DJP Bengkulu dan Lampung tahun 2016 sampai dengan tahun 2018 (Tabel 4.1) diketahui bahwa sektor usaha Industri Pengolahan (kode KLU : 10 s.d. 33) menempati posisi teratas, sedangkan posisi kedua teratas tahun 2016 sampai dengan tahun 2018 ditempati oleh sektor usaha Perdagangan Besar Dan Eceran; Reparasi Dan Perawatan Mobil Dan Sepeda Motor (kode KLU 45 s.d. 47). Untuk tahun 2019 sektor usaha Perdagangan Besar Dan Eceran; Reparasi Dan Perawatan Mobil Dan Sepeda Motor (kode KLU 45 s.d. 47) menempati posisi teratas dalam penerimaan di Kantor Wilayah DJP Bengkulu dan Lampung, sedangkan posisi kedua teratas ditempati oleh Industri Pengolahan (kode KLU 45 s.d. 47). Untuk posisi ketiga dari tahun 2016 s.d. 2019 secara berturut-turut ditempati oleh sektor usaha Konstruksi (kode KLU 41 s.d. 43).

Kemudian jika melihat Tabel 4.4 (Tabel Penerimaan Sektoral Rata-Rata Wajib Pajak Badan Kantor Wilayah DJP Bengkulu dan Lampung Tahun 2016-2019) diketahui bahwa rata-rata penerimaan pajak rutin terbesar 
Wajib Pajak Badan per-sektor usaha periode tahun 2016-2018 di lingkungan Kantor Wilayah DJP Bengkulu dan Lampung adalah : pertama, berada pada sektor usaha Industri Pengolahan (Kode KLU : 10 s.d. 33), sedangkan posisi kedua adalah sektor usaha Pengadaan Listrik, Gas, Uap/ Air Panas Dan Udara Dingin (Kode KLU : 35). Untuk tahun 2019 sektor usaha Pengadaan Listrik, Gas, Uap/ Air Panas Dan Udara Dingin (Kode KLU : 35) berada pada posisi pertama sedangkan Industri Pengolahan (Kode KLU : 10 s.d. 33) menempati posisi kedua. Untuk posisi ketiga pada tahun 2016 ditempati oleh sektor usaha Jasa Keuangan Dan Asuransi (Kode KLU : 64 s.d. 66), sedangkan tahun 2017-2019 posisi ketiga secara berturut-turut ditempati oleh sektor usaha Pertambangan Dan Penggalian (Kode KLU : 05 s.d. 09).

Dengan membandingkan sektor usaha di atas (data penerimaan sektoral dan data penerimaan sektoral rata-rata) maka diketahui bahwa sektor usaha Industri Pengolahan (Kode KLU : 10 s.d. 33) adalah sektor usaha yang potensial dan perlu mendapatkan pembinaan dan pengawasan khusus.

\section{Pemetaan (Mapping) Berdasarkan Penerimaan Hasil Pemeriksaan Pajak}

Berdasarkan Tabel 4.11 (Tabel Rata-Rata Penerimaan Hasil Pemeriksaan Per-Sektor Usaha Wajib Pajak Badan) diketahui bahwa untuk periode tahun 2016 sampai dengan tahun 2019 tidak ada sektor usaha yang terusmenerus dan berkesinambungan menjadi penyumbang penerimaan pajak terbesar melalui kegiatan pemeriksaan pajak. Pada tahun 2016 sektor usaha penyumbang penerimaan tebesar secara rata-rata dari kegiatan pemeriksaan pajak adalah sektor usaha Pengadaan Air, Pengelolaan Sampah Dan Daur Ulang, Pembuangan Dan Pembersihan Limbah Dan Sampah (kode KLU : 36 s.d. 39); untuk tahun 2017, sektor usaha Perdagangan Besar Dan Eceran; Reparasi Dan Perawatan Mobil Dan Sepeda Motor (kode KLU : 45 s.d. 47); untuk tahun 2018, sektor usaha Pertambangan Dan Penggalian (kode KLU : 05 s.d. 09); dan untuk tahun 2019, sektor usaha Industri Pengolahan (kode KLU : 10 s.d. 33).

Selanjutnya berdasarkan Tabel 4.14 (Tabel Rata-Rata Penerimaan Hasil Pemeriksaan Khusus Per-Sektor Usaha Wajib Pajak Badan) diketahui bahwa rata-rata penerimaan hasil Pemeriksaan Khusus per-sektor usaha Wajib Pajak Badan tahun 2016-2019 cukup signifikan dengan penerimaan rata-rata tertinggi pada tahun 2016 berada pada sektor usaha Industri Pengolahan (kode KLU : 10 s.d. 33); untuk tahun 2017 dan tahun 2018, sektor usaha Pertambangan Dan Penggalian (kode KLU : 05 s.d. 09); dan untuk tahun 2019, sektor usaha Pengadaan Air, Pengelolaan Sampah Dan Daur Ulang, Pembuangan Dan Pembersihan Limbah Dan Sampah (kode KLU : 36 s.d. 39).

Kemudian berdasarkan Tabel 4.17 (Tabel Rata-Rata Penerimaan Hasil Pemeriksaan Rutin Dan Pemeriksaan Tujuan Lain Per-Sektor Usaha Wajib Pajak Badan) diketahui bahwa pada tahun 2016 rata-rata terbesar dari penerimaan hasil Pemeriksaan Rutin dan Pemeriksaan Tujuan Lain adalah bersumber dari sektor usaha Pengadaan Air, Pengelolaan Sampah Dan Daur Ulang, Pembuangan Dan Pembersihan Limbah Dan Sampah (kode KLU : 36 s.d. 39); untuk tahun 2017, sektor usaha Pertanian, Kehutanan Dan Perikanan (kode KLU : 01 s.d. 03); dan untuk tahun 2018 sampai dengan tahun 2019 sektor usaha Pertambangan Dan Penggalian (kode KLU : 05 s.d. 09).

Jika melihat rata-rata hasil pemeriksaan pajak, maka sektor usaha penyumbang penerimaan rata-rata hasil pemeriksaan pajak terbesar per-sektor usaha adalah:

1. Pengadaan Air, Pengelolaan Sampah Dan Daur Ulang, Pembuangan Dan Pembersihan Limbah Dan Sampah (kode KLU : 36 s.d. 39);

2. Perdagangan Besar Dan Eceran; Reparasi Dan Perawatan Mobil Dan Sepeda Motor (kode KLU : 45 s.d. 47);

3. Pertambangan Dan Penggalian (kode KLU : 05 s.d. 09);

4. Industri Pengolahan (kode KLU : 10 s.d. 33).

Sedangkan sektor usaha penyumbang penerimaan rata-rata terbesar (dua tahun berturut-turut, tahun 2017-2018) hasil Pemeriksaan Khusus adalah Pertambangan Dan Penggalian (kode KLU : 05 s.d. 09). Kemudian sektor usaha usaha penyumbang penerimaan rata-rata terbesar (dua tahun berturut-turut, tahun 2018-2019) hasil Pemeriksaan Rutin dan Pemeriksaan Tujuan Lain adalah Pertambangan Dan Penggalian (kode KLU : 05 s.d. 09). Sehingga dengan membandingkan sektor-sektor usaha di atas maka didapatkan sektor usaha Pertambangan Dan Penggalian (kode KLU : 05 s.d. 09) adalah sektor usaha yang potensial dan perlu mendapatkan pembinaan dan pengawasan khusus.

\section{Keterbatasan Penelitian}

Studi penelitian yang dilakukan memiliki keterbatasan dan kekurangan dalam penyusunannya sehingga masih jauh dari kesempurnaan. Beberapa keterbatasan yang dapat diungkapkan adalah :

1. Keterbatasan dalam pengungkapan data identitas Wajib Pajak yang memberikan pembayaran pajak besar hasil kegiatan pemeriksaan pajak karena dibatasi oleh Pasal 34 Undang-undang Ketentuan Umum dan Tata Cara Perpajakan Nomor 6 Tahun 1983 sebagaimana telah diubah terakhir dengan Undangundang Nomor 28 Tahun 2007, yang berbunyi : "Setiap Pejabat dilarang memberitahukan kepada pihak 
lain segala sesuatu yang diketahui atau diberitahukan kepadanya oleh Wajib Pajak dalam rangka jabatan atau pekerjaannya untuk menjalankan ketentuan peraturan perundang-undangan perpajakan";

2. Data yang digunakan dalam penelitian ini hanya berasal dari data internal Direktorat Jenderal Pajak (DJP) yaitu data penerimaan sektoral dan data penerimaan hasil pemeriksaan per-sektor usaha sehingga pengujian data yang ada belum dapat dikatakan valid 100\%;

3. Penelitian ini hanya berupaya menghasilkan pemetaan (mapping) secara basis wilayah yang diharapkan hasilnya mendekati gambaran umum sektor usaha/ KLU Wajib Pajak Badan yang potensial di wilayah Provinsi Bengkulu dan Provinsi Lampung, sehingga hasil pemetaan (mapping) tersebut tidak dapat digeneralisir pada seluruh kantor pelayanan pajak (KPP) di lingkungan Kantor Wilayah DJP Bengkulu dan Lampung.

\section{Kesimpulan dan Implikasi \\ Kesimpulan}

Berdasarkan hasil penelitian dan pembahasan maka dapat disimpulkan sebagai berikut:

1. Mengacu kepada hasil pemeriksaan pajak di lingkungan Kantor Wilayah DJP Bengkulu dan Lampung tahun 2016 sampai dengan tahun 2019 maka dapat diidentifikasi pemetaan (mapping) Klasifikasi Lapangan Usaha (KLU) yang potensial, yaitu dengan membandingkan penerimaan rutin terbesar sektoral dan penerimaan rata-rata rutin terbesar sektoral serta dengan membandingkan antara penerimaan hasil pemeriksaan pajak terbesar per-sektor usaha dengan penerimaan rata-rata terbesar hasil Pemeriksaan Khusus serta penerimaan rata-rata terbesar hasil Pemeriksaan Rutin dan Pemeriksaan Tujuan Lain.

2. Dari pemetaan (mapping) Wajib Pajak Badan per-sektor usaha, maka dapat diketahui bahwa Wajib Pajak Badan yang potensial di lingkungan Kantor Wilayah DJP Bengkulu dan Lampung berdasarkan penerimaan sektoral usaha maupun penerimaan hasil pemeriksaan pajak. Adapun sektor usaha tersebut adalah:

\section{Implikasi}

a. Idustri Pengolahan (kode KLU : 10 s.d. 33); dan

b. Pertambangan Dan Penggalian (kode KLU : 05 s.d. 09).

Beberapa implikasi dalam penelitian ini adalah sebagai berikut:

1. Terkait penelitian berdasarkan administrasi perencanaan kegiatan pemeriksaan pajak di lingkungan Kantor Wilayah DJP Bengkulu dan Lampung guna mengoptimalkan penerimaan dari pemeriksaan pajak maka sebaiknya lebih mengedepankan penerapan kebijakan Pemeriksaan Khusus bagi Wajib Pajak Badan dibandingkan dengan Pemeriksaan Rutin dan Pemeriksaan Tujuan Lain karena dengan Pemeriksaan Khusus maka pemeriksaan pajak yang dilakukan otomatis masuk dalam kriteria Pemeriksaan Lapangan dengan ruang lingkup seluruh jenis pajak (All Taxes).

2. Agar dilakukan pembinaan dan pengawasan yang lebih khusus terhadap Wajib Pajak yang potensial, yaitu Wajib Pajak dari sektor usaha tertentu yang menyumbang penerimaan pajak terbesar di Kantor Wilayah DJP Bengkulu dan Lampung baik dengan sosialisasi peraturan perpajakan terbaru yang sesuai kegiatan usaha Wajib Pajak ataupun dengan konseling langsung kepada Wajib Pajak terkait dengan kegiatan usahanya.

3. Agar Account Representative (AR) di seluruh kantor pelayanan pajak di lingkungan Kantor Wilayah DJP Bengkulu dan Lampung melakukan analisis risiko ketidakpatuhan Wajib Pajak tertentu yang berada pada sektor usaha prioritas berdasarkan metode analisis laporan keuangan komparatif. Berdasarkan analisis risiko ini maka dapat dilihat Wajib Pajak yang tidak patuh yang perlu dilakukan himbauan perpajakan dan jika perlu diusulkan untuk dilakukan pemeriksaan dengan tujuan dalam rangka pembinaan.

4. Selain itu Kantor Wilayah DJP Bengkulu dan Lampung juga dapat menggunakan pendekatan lainnya dalam melakukan pemetaan (mapping) sektor usaha Wajib Pajak Badan yang potensial yaitu dengan menggunakan data laporan keuangan Wajib Pajak mengenai peredaran usaha, asset maupun data lainnya.

5. Diperlukan pembinaan serta pengembangan kapasitas pegawai yang berkesinambungan di lingkungan Kantor Wilayah DJP Bengkulu dan Lampung terutama bagi pegawai yang langsung berhadapan dengan Wajib Pajak yaitu para Account Representative (AR) dan Fungsional Pemeriksa Pajak dengan sarana pendidikan dan pelatihan yang diadakan baik di tingkat kantor wilayah, kantor pusat maupun pelatihan/ in house training yang diadakan di kantor pelayanan pajak (KPP).

6. Untuk penelitian selanjutnya agar didapatkan penelitian yang lebih valid, maka dalam melakukan pemetaan (mapping) KLU Wajib Pajak Badan yang potensial selain dengan menggunakan data internal Direktorat Jenderal Pajak (DJP) juga sebaiknya dengan menggunakan data eksternal seperti data dari 
instansi/ lembaga Pemerintah Pusat lainnya, instansi/ Lembaga Pemerintah Daerah, asosiasi-asosiasi sektor usaha, dll.

7. Untuk penelitian selanjutnya agar didapatkan hasil pemetaan (mapping) yang lebih mencerminkan kondisi pada kantor pelayanan pajak (KPP), maka dapat mempersempit ruang lingkup penelitian yaitu hanya meneliti sektor usaha/ KLU Wajib Pajak Badan yang potensial di tingkat kantor pelayanan pajak (KPP).

\section{Daftar Pustaka}

Barusman, Tina Miniawati \& Pratiwi, Tia Rizna. 2016. Pengaruh Pendapatan Asli Daerah dan Belanja Modal Terhadap Peningkatan Indeks Pembangunan Manusia pada Pemerintah Daerah di Provinsi Lampung Periode 2013-2015. Jurnal Ekonomi dan Bisnis.

Hakim, Abdul. 2010. Statistika Deskriptif Untuk Ekonomi \& Bisnis. Yogyakarta : Penerbit Ekonisia.

Peraturan Direktur Jenderal Pajak Nomor : PER-23/PJ/2013 tentang Standar Pemeriksaan

Peraturan Menteri Keuangan 17/PMK.03/2013 tentang Tata Cara Pemeriksaan

Peraturan Menteri Keuangan 17/PMK.03/2013 tentang Perubahan Atas Peraturan Menteri Keuangan Nomor 17/PMK.03/2013 Tentang Tata Cara Pemeriksaan

Pandiangan, Liberti 2008. Modernisasi dan Reformasi Pelayanan Perpajakan. Jakarta : Elex Media Computindo, hlm. 65 .

Sekaran, U. 1992. Research Methods For Business.

Siti Kurnia Rahayu. 2009. Perpajakan Indonesia : Konsep dan Aspek Formal. Yogyakarta : Graha Ilmu.

Suandy, E. 2005. Hukum Pajak, edisi ketiga. Jakarta : Salemba Empat.

Sugiyono. 2005. Memahami Penelitian Kualitatif. Bandung: CV. Alfabeta

Surat Edaran Direktur Jenderal Pajak nomor : SE-03/PJ/2013 tentang Klasifikasi Lapangan Usaha.

Surat Edaran Direktur Jenderal Pajak Nomor SE-15/PJ/2018 tentang Kebijakan Pemeriksaan

Soedarsa, Herry Gunawan, Chairul Anwar \& Shanti. 2014. Pengaruh Audit Manajemen Sumber Daya Manusia terhadap Kinerja Karyawan (Studi Kasus pada PT. Gramedia Asri Media Bandar Lampung). Jurnal Akuntansi \& Bisnis. Vol, 5, No; 1.

Undang-Undang No. 28 Tahun 2007 tentang Ketentuan Umum dan Tatacara Perpajakan sebagaimana telah dirubah terakhir dengan Undang-Undang No. 16 Tahun 2009.

Waluyo. 2011. Perpajakan Indonesia. Buku 2. Edisi 10. Jakarta : Penerbit Salemba Empat.

Zain, Mohammad. 2005. Manajemen Perpajakan. Jakarta : Penerbit Salemba Empat 